\title{
ANALISIS KESALAHAN BERBAHASA INDONESIA PADA MEDIA BERITA BERBASIS DIGITAL
}

\author{
Indar Jaya \\ Universitas Putera Batam (UPB), Batam, Kepri, Indonesia \\ pb201510003@upbatam.ac.id \\ Yunisa Oktavia \\ Universitas Putera Batam (UPB), Batam, Kepri, Indonesia \\ Yunisa@puterabatam.ac.id
}

\begin{abstract}
One of the media used to read news is digital-based media. However, in digital media, we often encounter errors in Indonesian. We still often encounter errors, syntax errors, and morphological errors when communicating or reading news in various media. Therefore, these errors will be the main discussion in this article. The main purpose of writing this article is to explain errors, morphological errors, and language syntax errors in internet-based news media. In addition, another goal is to provide improvements that are by the writing of Indonesian writing. The descriptive method is used as the main method in analysing Indonesian writing errors. The method of collecting data or information is done by searching, reading, and understanding the content of news on the internet. The results of the analysis of errors in the use of Indonesian in internetbased news media found that there were still many media that made mistakes starting from the news title to the content of the news that was written.
\end{abstract}

Keywords: Language Errors, Digital, News Media.

\section{PENDAHULUAN}

Bahasa adalah salah satu alat penting yang dimiliki manusia dalam berkomunikasi baik secara langsung atau tidak langsung. Hampir semua negara memiliki bahasa sendiri yang ditetapkan oleh negara sebagai bahasa utama yang digunakan dalam berkomunikasi. Seperti halnya dengan negara lain, Indonesia menerapkan bahasa Indonesia sebagai bahasa resmi dalam berkomunikasi. Terdapat berbagai bentuk media komunikasi, media massa adalah satu di antara bentuk komunikasi yang bisa digunakan. Media massa terdiri berbagai macam bentuk di antaranya adalah media berita berbasis internet.

Media berita merupakan bagian dari media massa yang berfokus dalam menyampaikan berita terhadap publik melalui media cetak, penyiaran, dan berbasis internet. Secara umum, bagi media-media yang berada di Indonesia menyampaikan berita menggunakan bahasa Indonesia sebagaimana bahasa Indonesia yang merupakan bahasa 
utama dan bahasa kesatuan. Namun demikian, kita masih saja menemukan kesalahan-kesalahan yang dianggap tidak cocok pada pedoman penulisan bahasa Indonesia.

Terjadinya kesalahan berbahasa Indonesia baik itu disadari atau tidak akan menjadi suatu hal yang fatal. Kesalahan penulisan bahasa Indonesia pada media digital bisa menyebabkan kerancuan terhadap informasi yang ditulis. Dengan adanya kerancuan tersebut akibatnya susunan kalimat bisa memberikan tafsiran yang salah atau makna yang berbeda. Dengan demikian, dalam penulisan berita harus menggunakan penggunaan bahasa Indonesia yang sesuai kaidahnya.

Ejaan merupakan susunan dari gambaran atau tampilan bunyi bahasa yang berisi kata-kata atau kalimat dan lainnya yang berbentuk teks (tulisan) atau aksara (huruf-huruf) yang menyertakan pemakaian tanda baca, (Sriyanto, 2015). Oleh karena itu kesalahan ejaan bisa diartikan sebagai bentuk kesalahan penulisan kata, kalimat serta tanda baca. Kesalahan ejaan pada media berita sering ditemukan pada judul dan isi berita.

Manaf

(Manaf,

2009)

mengemukakan bahwasanya sintaksis termasuk ke dalam kelompok ilmu bahasa (linguistik) atau yang di mana membahas kajian tentang susunan internal kalimat. Menurut Wiyanti (Wiyanti et al., 2017) dalam jurnalnya menjelaskan bahwa kesalahan sintaksis berarti kesalahan-kesalahan dalam penataan kalimat seperti pengurutan kata, penyusunan frasa, klausa, logika, dan perpaduan kalimat. Penggunaan kata tidak baku, kalimat ambigu, kalimat tidak tepat, kalimat rancu, dan kalimat pleonasme juga termasuk ke dalam kesalahan sintaksis.

Sedangkan, Morfologi merupakan cabang ilmu linguistik (bahasa) yang bertujuan untuk mengkaji berbagai bentuk susunan kata serta pengaruh perubahan bentuknya dengan arti kata untuk mengenali rangkaian dasar bahasa sebagai rangkaian gramatikal, (McCarthy, 2002). Morfologi tidak hanya mengkaji susunan bentuk kata, tetapi morfologi juga mengkaji proses rangkaian membentuk kata-kata yang di mana dikenal dengan istilah proses morfologi. Proses morfologi pada bahasa Indonesia terdiri dari 3 proses yakni, proses reduplikasi kata (pengulangan), proses pemajemukan kata, dan proses afiksasi, (Chaer, 2008). Kesalahan yang diakibatkan oleh kesalahan pemilihan afiks, kesalahan penggunaan kata ulang, kesalahan penyusunan kata majemuk, dan kesalahan pemilihan bentuk kata bisa dimaknai sebagai kesalahan morfologi, (Tarigan \& Tarigan, 1988).

Permasalahan seperti kesalahan ejaan, kesalahan sintaksis, dan kesalahan morfologi menjadi masalah utama dalam penulisan berita di mediamedia internet. Dengan adanya kesalahan-kesalahan tersebut membuat penulis memutuskan untuk menulis artikel ilmiah yang berjudul "Analisis Kesalahan Berbahasa Indonesia Pada Media Berita Berbasis Digital". Sebelum menulis artikel ini saya melakukan analisis studi kasus terhadap kasus-kasus yang saya temukan. Analisis studi kasus dengan mengambil beberapa contoh kasus media berita di internet yang sesuai dengan judul artikel ini. Tujuan analisis dilakukan untuk lebih mendalami dan memahami isi dari kasus yang diangkat. 


\section{METODE ANALISIS}

Metode deskriptif adalah satu cara yang dipakai dalam mendeskripsikan hasil analisis penelitian namun tidak dalam penarikan simpulan secara luas. Metode analisis yang saya gunakan dalam studi kasus adalah mencari, membaca, dan memahami isi berita untuk menemukan kesalahankesalahan dalam berita tersebut. Datadata yang menjadi fokus utama adalah data-data yang memiliki kesalahan ejaan, morfologi, dan sintaksis. Semua data diambil menggunakan teknik pengumpulan data.

\section{PEMBAHASAN}

Semua berita yang menjadi objek studi kasus diambil dari beberapa media berita di internet yaitu, tribunnews.com, detik.com, kompas.com, dan liputan6.com. Berikut ini hasil daftar analisis berita yang ditemukan memiliki kesalahan.

\section{Analisis Kesalahan Berbahasa Pada Media Berita Tribunnews.com}

Kesalahan berbahasa pada berita "Indonesia Ngebet Masuki Era Kendaraan Listrik, Industri Kalang Kabut, Baiknya Bagaimana?".

TRIBUNNEWS.COM, JAKARTA - Pemerintah Indonesia memasang
target 25 persen mobil yang dijual pada 2025 merupakan battery
electric vehicle (BEV) alias mobil listrik.

Kesalahan sintaksis: Pemerintah Indonesia memasang target 25 persen mobil yang dijual pada 2025 merupakan battery electric vehicle (BEV) alias mobil listrik.

Perbaikan: Pemerintah Indonesia memasang target 25 persen mobil yang dijual pada tahun 2025 merupakan battery electric vehicle (BEV) alias mobil listrik. Penambahan kata 'Tahun' pada kalimat tersebut membuat kalimat tersebut tidak rancu.

"PDB per-kapita Indonesia saat ini masih di kisaran 4.000 dola

AS, sehingga daya beli masyarakat untuk mobil masih di bwah Rp 300 juta," kata Shodiq.

Kesalahan sintaksis: di bwah.

Perbaikan: di bawah

Target ambisius tersebut tentu akan mengubah struktur industri otomotif nasional, mulai dari pemanufaktur, pemasok

komponen, hingga konsumen, dimana perubahan mobil dari mesin pembakaran internal atau internal combustion engine (ICE) ke BEV dinilai sangat radikal.

Kesalahan ejaan: dimana.

Perbaikan: di mana.

"PDB per-kapita Indonesia saat ini masih di kisaran 4.000 dola AS, sehingga daya beli masyarakat untuk mobil masih di bwah Rp 300 juta," kata Shodiq.

Kesalahan ejaan: Rp 300 juta

Perbaikan: 300 juta rupiah atau tiga ratus juta rupiah atau Rp300.000.000,00

Kesalahan berbahasa pada berita "Kecelakaan Truk Timpa Minibus di Tol Cipularang, 1 Tewas dan 7 Terluka".

"Kendaraan datang dari arah Bandung menuju Jakarta, setiba di lokasi kejadian di jalan sedikit menurun, truk hiang kendali kemudian terguling lalu menimpa kendaraan minibus Hyundai yang berusaha menyalip dari sebelah kiri," ujar Ipda Jamal Nasir, dilokasi kejadian, Sabtu

(16/10/2021)

Kesalahan ejaan: ujar Ipda Jamal Nasir, dilokasi kejadian,

Perbaikan: di lokasi kejadian.

"Kendaraan datang dari arah Bandung menuju Jakarta, setiba di lokasi kejadian di jalan sedikit menurun, truk hiang kendali kemudian terguling lalu menimpa kendaraan minibus Hyundai yang berusaha menyalip dari sebelah kiri," ujar Ipda Jamal Nasir, dilokasi kejadian, Sabtu

(16/10/2021)

Kesalahan sintaksis: hiang.

Perbaikan: hilang.

Kesalahan berbahasa pada berita “Penjualan Mobil Bensin Akan Disetop, Bagaimana Kesiapan Infrastruktur Pengisian Kendaraan Listrik?". 
Selanjutnya, Jawa Timur, Bali dan NTB sebanyak 29 unit yang tersebar di 23 lokasi, Sumatera mencapai 7 unit di 7 lokasi, dan Sulawesi mencapai 6 unit di 5 lokasi.

Kesalahan sintaksis: Selanjutnya, Jawa Timur, Bali dan NTB sebanyak 29 unit yang tersebar di 23 lokasi, Sumatera mencapai 7 unit di 7 lokasi, dan Sulawesi mencapai 6 unit di 5 lokasi.

Perbaikan: Penulisan kata "Sumatera" dalam isi berita tersebut merupakan kesalahan karena menggunakan kata tidak baku. Bentuk kata baku Sumatera adalah Sumatra, tidak memakai huruf 'e'.

Kesalahan berbahasa pada berita "Efek Domino Sanksi WADA, Bendera Indonesia Tak Berkibar di Podium Piala Thomas 2021, Nasib MotoGP?"

Sorotan akan tertuju saat momen setelah laga final dimana
empat tim yang sudah lolos ke babak semifinal akan berada di
podium juara.

Kesalahan: dimana.

Perbaikan: di mana

Kesalahan berbahasa pada berita "Sorotan Final Piala Thomas 2021: Misi Ganda Indonesia Buka Puasa Gelar \& Coreng Kesempurnaan China".

Dengan kelolosan China ke partai final Thomas 2021 juga, maka peluang mereka untuk mengawinkan gelar juara dengan Pial Uber terbuka lebar.

Kesalahan sintaksis: Pial

Perbaikan: Piala

\section{Analisis Kesalahan Berbahasa Pada Media Berita Detik.com}

Kesalahan berbahasa pada berita "Laptop Lelet Pas Baru Dinyalain? Ini Dia Solusinya".

$\begin{aligned} & \text { Laptop Lelet Pas Baru Dinyalain? Ini Dia } \\ & \text { Solusinya! }\end{aligned}$
Kesalahan sintaksis: Penggunaan

kalimat tidak baku pada judul berita
"Laptop Lelet Pas Baru Dinyalain? Ini Dia Solusinya!".

Perbaikan: Laptop Lambatt Ketika Dinyalakan? Ini Solusinya!

Kesalahan morfologi: Pembentukan kata 'dinyalain' yang tidak sesuai.

Perbaikan: dinyalakan

Kesalahan berbahasa pada berita "2 Kecelakaan Pesawat dalam Dakwaan 100 Tahun Bui untuk Eks Pilot Boeing".

Pihak maskapai mengatakan terdapat 149 penumpang dan delapan awak yang berada alam penerbangan ET302 tersebut. Diantara para korban, terdapat 32 warga Kenya, 18 Kanada, 8 Amerika Serikat dan 7 warga negara Inggris

Kesalahan ejaan: Diantara

Perbaikan: Di antara

Kesalahan berbahasa pada berita "Kesaksian Faisal yang Selamat Susur Sungai Maut di Ciamis: Airnya Dalam". Faisal sendiri saat itu sempat ikut tenggelam. Namun la berhasil selama
setelah ditolong oleh sesosok perempuan misterius. la menceritakan saat itu dirinya melihat perempuan berhijab yang mengulurkan tangan.

Kesalahan ejaan: Namun la berhasil selamat setelah ditolong oleh sesosok perempuan misterius.

Perbaikan: Namun, la berhasil selamat setelah ditolong oleh sosok perempuan misterius. Harus ada tanda koma setelah kata namun.

Kesalahan berbahasa pada berita "Rocky Gerung Sebut Ganjar-Puan Bodoh Bagi Milenial, Aria Bima: Asal Bacot!".

"Soal bodoh dan pintar itu tergantung dari sudut mana melihat dan mengkategorikannya. Tentu dengan masing masing dimensinya," kata Aria Bima saat ditemui detikcom di Solo, Jumat (15/10/2021) malam.

Kesalahan morfologi: Tentu dengan masing masing dimensinya

Perbaikan: Tentu dengan masingmasing dimensinya

Analisis Kesalahan Berbahasa Pada Media Berita Kompas.com 
Kesalahan berbahasa pada berita "Lawan China di Final Thomas Cup, Bagaimana Peluang Indonesia?".

Darisektor ganda pertama, Christian memprediksi, yang akan dipasang tim
China untuk menghadapi Kevin/Marcus bukan ganda nomor satu dari negeri Tirai Bambu.

Kesalahan sintaksis: Darisektor ganda pertama,

Perbaikan: Dari sektor ganda pertama,

Kesalahan berbahasa pada berita" Man United Gagal Menang Lagi, Bagaimana Nasib Solskjaer?"

"Kami tidak pantas mendapatkan poin karena memang tidak tampil sesuasi standar Premier League," kata Solskjaer dikutip dari situs Daily Mail.

Kesalahan sintaksis: "Kami tidak pantas mendapatkan poin karena memang tidak tampil sesuasi standar Premier League,"

Perbaikan: kata 'sesuasi' diubah menjadi sesuai, "Kami tidak pantas mendapatkan poin karena memang tidak tampil sesuai standar Premier League,"

Kesalahan berbahasa pada berita "Apa Itu Startup dan Perbedaanya dengan Perusahaan Konvensional?".

Apa Itu Startup dan Perbedaanya dengan Perusahaan Konvensional?

Kesalahan sintaksis: Hanya terdapat satu huruf ' $n$ ' pada kata 'perbedaanya' di judul berita "Apa Itu Startup dan Perbedaanya dengan Perusahaan Konvensional?"

Perbaikan: Seharusnya ditulis, "Apa Itu Startup dan Perbedaannya dengan Perusahaan Konvensional

JAKARTA, KOMPAS.com - Tahukah Anda apa itu startup? Istilah tersebut sudah sangat sering mendengarnya. Kata Startup sendiri adalah berasal dar serapan dari Bahasa Inggris yang berarti bisnis yang baru saja dirintis atau bisnis rintisan

Kesalahan sintaksis: Pada paragraf pertama berita terdapat kalimat rancu. Perbaikan: Tahukah Anda apa itu startup? Istilah tersebut sudah sangat sering kita mendengarnya. Kata startup sendiri berasal dari serapan bahasa Inggris yang berarti bisnis yang baru saja dirintis atau bisnis rintisan.

Startup adalah perusahaan rintisan yang belum lama beroperasi. Dengan kat lain, startup artinya perusahaan yang baru masuk atau masih berada pada fase pengembangan atau penelitian untuk terus menemukan pasar meupun mengembangkan produknya.

Kesalahan sintaksis: meupun

Perbaikan: mau pun

Perkembangan perusahaan rintisan di Indonesia memang cukup kencang dalam beberapa tahun belakangan ini. Karena pesatnya perkembangan startup, seringkali menciptakan disrupsi ekonomi.

Kesalahan ejaan: seringkali

Perbaikan: sering kali

\section{Analisis Kesalahan Berbahasa Pada Media Berita Liputan6.com}

Kesalahan berbahasa pada berita "BNPB: Prioritas Penanganan Gempa Bali, Evakuasi Korban dan Kelompok Rentan".

"Tercatat bantuan di wlayah Karangasem antara lain 20 tenda keluarga, 60 paket makanan saji, 443 paket lauk pauk, dan 153 paket makanan tambahan gizi. Bantuan dengan jenis dan

Kesalahan morfologi: lauk pauk

Perbaikan: lauk-pauk

ntuk penanganan pengungsi dan korban gempa, harus dipastikan ketersediaan logistik, tenda makanan, terutama makanan untuk bayi, ibu hamil dan lansia. Juga obat-obatan, pasokan air dan MCK," tandas Ganip.

Kesalahan ejaan: Terdapat dua tanda baca koma setelah kata tenda.

Perbaikan: "Untuk penanganan pengungsi dan korban gempa, harus dipastikan ketersediaan logistik, tenda, makanan, terutama makanan untuk bayi, ibu hamil dan lansia. Juga obatobatan, pasokan air dan MCK," tandas Ganip.

Dia menyebut jika pelaku usaha kelas besar dan menengah bidang Obat,Kosmetik dan barang
gunaan pasti mereka siap tapi pelaku UMKM akan mengalami kesulitan. Kesalahan ejaan: Tidak ada spasi setelah tanda koma, sebelum kata kosmetik.

Kesalahan ejaan: Kata obat dan kosmetik tidak perlu menggunakan huruf kapital di awal kata. 
Perbaikan: Dia menyebut jika pelaku usaha kelas besar dan menengah bidang obat, kosmetik dan barang gunaan pasti mereka siap tapi pelaku UMKM akan mengalami kesulitan.

\section{KESIMPULAN}

Hasil dari pembahasan di atas bisa disimpulkan bahwa masih banyak kesalahan-kesalahan berbahasa pada media berita berbasis internet. Kesalahan-kesalahan banyak dijumpai ialah kesalahan sintaksis dan kesalahan ejaan, kesalahan dalam menggunakan kata tidak baku, kesalahan kata depan, kesalahan tik, kesalahan penggunaan huruf kapital serta kesalahan penggunaan penulisan rupiah.

Saran, Sebaiknya dilakukan pemeriksaan isi berita sebelum dipublikasikan. Jika terdapat kesalahankesalahan berbahasa dalam penulisan berita agar segera diperbaiki. Selain itu, utamakan penggunaan kata-kata baku dan kata-kata serapan yang benar.

\section{SUMBER BERITA}

1.https://www.tribunnews.com/bisnis/ 2021/10/16/penjualan-mobil-bensinakan-disetop-how-kesisian-infrakturpengisian-kendaraan-listrik 2.https://inet.detik.com/video/211016 054/laptop-lelet-pas-baru-dinyalain-inidia-solution

3.https://www.tribunnews.com/otomo tif/2021/10/15/indonesia-ngebetenteri-era-kendaraan-listrik-industrikalang-kabut-baik-how 4.https://www.tribunnews.com/sport/ 2021/10/17/sorotan-final-pialathomas-2021-misi-ganda-indonesiabuka-puasa-gelar-coreng-kecepatanchina

5.https://news.detik.com/internasional /d-5770620/2-kecelakaan-pesawat- dalam-dakwaan-100-tahun-bui-untukeks-pilot-boeing/2

6.https://www.liputan6.com/bisnis/rea d/4686672/obat-dan-kosmetik-hargabersertifikat-halal-pengusaha-mintagovernment-bantu-umkm

7.https://money.kompas.com/read/20 20/10/21/093719826/apa-itu-startupdan-bedaya-dengan-kompas-

konvensional?page=all

\section{REFERENSI}

Chaer, A. (2008). Morfologi bahasa Indonesia: pendekatan proses. Rineka Cipta.

Manaf, N. A. (2009). Sintaksis: Teori dan Terapannya dalam Bahasa Indonesia. Padang: Sukabina Press.

McCarthy, A. C. (2002). An introduction to English morphology: words and their structure. Edinburgh: Edinburgh University Press.

Sriyanto. (2015). Seri Penyuluhan Bahasa Indonesia: Ejaan. In E. R. Adiati (Ed.), Seri Penyuluhan Bahasa Indonesia: Ejaan (Vol. 58, Issue 12). Pembinaan dan Pemasyarakatan Badan Pengembangan dan Pembinaan Bahasa Kemendikbud. https://doi.org/10.1128/AAC.0372 8-14

Tarigan, H. G., \& Tarigan, D. (1988). Pengajaran analisis kesalahan berbahasa. Angkasa, Bandung.

Wiyanti, E., Setiawati, S., \& Sumadyo, B. (2017). Tipe-Tipe Kesalahan Sintaksis pada Karangan Siswa Kelas XI SMA Bina Spora Mandiri Cigombong Bogor. DEIKSIS, 9(03), 300.

https://doi.org/10.30998/deiksis.v 9i03.680 